\title{
Bringing a Small Archival Collection to Life on the Web: Remembering the Real Winnie
}

\author{
Sally Wilson \\ Ryerson University, \\ Canada \\ swilson@ryerson.ca
}

\author{
Marina Morgan \\ Ryerson University, \\ Canada \\ marina.morgan@gmail.com
}

Keywords: schema; metadata mapping; cataloguing; digital collections; digitization; Dublin Core; World War I; Great War; bear; Winnie; Winnie-the-Pooh.

\section{Abstract}

The purpose of this poster is to provide insight into the processes involved in creating an interdisciplinary online exhibition focused on a unique chapter of Canadian history from World War I. The exhibition focuses on the Colebourn Family Archive comprising digitized photographs and ephemera of Canadian soldier and veterinarian Harry Colebourn (1887-1947) who purchased a pet bear named Winnie who later became A. A. Milne's inspiration for the classic Winnie-the-Pooh children's book series.

\section{Introduction}

Remembering the Real Winnie: The World's Most Famous Bear Turns 100 is a collaborative, interdisciplinary project that focuses on a unique chapter of Canadian history from WWI. It is based on the Colebourn Family Archives, a collection of photographs, diaries, images, books, and objects, which has been lent to Ryerson University for the purposes of this project. The online exhibit presents the archival content of the collection along with browsable diaries, dynamic maps, and interactive $3 \mathrm{D}$ objects. ${ }^{1}$

\section{Background}

Harry Colebourn was a Canadian veterinarian who, on his train journey from Winnipeg to Valcartier to join the Canadian troops heading to Europe at the beginning of WWI, purchased a bear cub in White River, Ontario, for 20 Canadian dollars. This cub was the mascot for Colebourn's regiment and was eventually donated to the London Zoo when the regiment deployed to France. While at the London Zoo, Winnie, named after Winnipeg where Colebourn lived, became popular with the public in general and with Christopher Robin Milne in particular. Christopher Robin called his teddy bear after Winnie, giving it the name Winnie-the-Pooh. This bear was the genesis of the Winnie-the-Pooh storybooks by Christopher Robin's father, A.A. Milne.

\section{Research Significance}

Through the creation of this online collection, this project has successfully brought various expertise together to explore innovative pedagogical practices. It provided the opportunity for students to gain experience in their fields of study and for librarians to contribute their expertise in designing an online environment for the preservation and analysis of photographs, texts and historical artefacts. This collaborative effort involved cataloguing, metadata mapping, digitization, and website design. The scholarly, online collection promotes research, teaching and learning and demonstrates the value of including the library in this type of collaborative project.

\footnotetext{
${ }^{1}$ http://therealwinnie.ryerson.ca/collection/
} 


\section{Tools Used to Create the Digital Collection}

\subsection{Oemka}

To create this digital collection we used Omeka, a free, flexible, and open source webpublishing platform. Omeka allows strong and flexible approaches to metadata representation, easy plug-in deployment, custom implementation of item types, and the addition of the full set of Dublin Core properties to the existing Dublin Core element set, including element refinements (Kucsma, Reiss, and Sidman). With the inclusion of community contributed plugins, you can import a wide variety of data in different formats, create maps, collect information from users, add tags, create timelines and more. For the Winnie project we used the CSV import, Dropbox, Extended Dublin Core, Internet Archive Book Reader, Geolocation and Simple Page plugins. We also customized the basic Omeka software to allow for the inclusion and display of 3D objects.

\subsection{Flipbooks}

Harry Colebourn kept several diaries during WWI. In the online collection these diaries could only be displayed open at selected pages. By using the Internet Archive BookReader plugin in Omeka we made the entire contents of the diaries browsable. Transcriptions were also made of the diary entries so that the content would be fully accessible to search engines both within Omeka and on the web.

\subsection{D Scanning}

Many of the items in the Colebourn Family Archive are three-dimensional objects including Harry Colebourn's vet bag and its contents. Photographic images were provided for these objects but the 2-dimensional representations are limited in how much information they can convey. A collaboration with the Department of Architectural Sciences at Ryerson enabled experimentation with scanning some of the contents of the vet bag and the bag itself. Since Omeka doesn't deal with 3D files natively, we loaded the files to SketchFab, a YouTube like service for 3D scans and embedded links to them from within Omeka. Users of the website are able to view the 3D objects in their browser and manipulate the object to see all sides.

\subsection{Geolocation and Mapping}

Omeka has a geolocation plugin, which was used to geolocate photographs with known locations on a map. To supplement this geolocation feature, an external mapping resource was used to create enhanced customized maps. Location information that Harry Colebourn recorded in his diaries during WWI was geocoded and added to the exhibit, along with information about leaves, duration of time spent in each location, types of visits, etc.

\section{Metadata Implementation}

Data for the project was supplied to the Library in the form of an Excel spreadsheet with multiple workbooks. Extensive corrections of the initial data were done to ensure both compatibility with Omeka software and the appropriate metadata standard, and consistency across the collection.

For this project we used Dublin Core metadata, the most widely adopted metadata standard that offers users the greatest flexibility. This descriptive metadata standard uses broad and generic elements that facilitate the discovery of resources, and provide contextual information useful in the understanding of the resources. Dublin Core provided controlled and structured descriptions of the resources through access points such as title, author, date, location, description and subject. Library of Congress subject headings were added to the metadata as were keyword tags to provide better access both within the collection and to optimize the data for discovery on the web via search engines. 
Additionally, separate Dublin Core records were created for each scanned item (photographs, diaries, scrapbooks) some located separately from the resource it describes, others embedded or packaged with it. Since many of the objects were three-dimensional, appropriate descriptive elements needed to be considered. In addition, decisions had to be made about which metadata elements should be displayed and how many were required to make the best use of the metadata within the website and more broadly on the web.

\section{Challenges}

We experienced considerable challenges with organization of the collection and the descriptive metadata. Omeka is organized with collections, items and files. We determined that a diary would be an item that worked well for creating flipbooks, but didn't work well for the transcriptions, which were eventually created as separate $\mathrm{html}$ pages and not within the item metadata. We also experienced some difficulties with the Excel spreadsheets of metadata as they were created by someone without any Dublin Core knowledge and required clean-up before they could be ingested into Omeka.

Furthermore, our inexperience with 3D scanning and its complexities resulted in our underestimating the amount of time required for this portion of the project. All of the items chosen were highly reflective which was problematic for scanning as the light used to make the readings is reflected from the object. We were able to solve the reflectivity problem by using an aerosol spray to coat the reflective objects. This allowed us to capture accurate readings of the geometry of the object, but considerable post-scanning clean up was required to map the surface materials back onto the scan.

\section{Conclusions}

This project focused on a unique chapter of Canadian and world history, and was brought to light by students, recent alumni and faculty from across the Ryerson campus, who co-developed this multidisciplinary project. This collection was intended to support the research activities of the students and faculty at Ryerson University as well as means of engaging the outside community. Many challenges were encountered during the course of this project. The use of the Dublin Core metadata standard allowed for a broad description of the resources and provided long-term preservation and access to cultural and communicative memories. Furthermore, the aim of the 3D scanning was to explore additional ways of interacting with the objects to see how 3D scanning could be used in this and future digital humanities projects.

Ultimately the project was well managed and run, but the complexity of working with multiple stakeholders and the changing scope of the website portion of the project resulted in several challenges. The website ensures that the entire collection is available to a much broader community for a longer period of time. The scholarly online collection promotes research, teaching and learning, and met its primary goals of increasing access and discoverability to a unique collection.

\section{References}

Dublin Core Metadata Initiative. (2012). DCMI Metadata Terms. Retrieved from http://dublincore.org/documents/dcmi-terms/.

Felicetti, A., Lorenzini, M. (2011). Metadata and Tools for Integration and Preservation of Cultural Heritage 3d Information. In: Proceedings of the 23rd International CIPA Symposium, Prague, 12-16 September 2011. Retrieved from http:/cipa.icomos.org/fileadmin/template/doc/PRAGUE/051.pdf

Kucsma, J., Reiss, K., \& Sidman, A. (2010). Using Omeka to build digital collections: The METRO case study. D-Lib Magazine, 16(3/4) doi:10.1045/march2010-kucsma.

Mapping Harry Colebourn (2014). Retrieved from http://therealwinnie.ryerson.ca/collection/mapping1.

Omeka Plugins. (2014). Retrieved from http://omeka.org/add-ons/plugins/. 
Remembering the Real Winnie 3D Scanning And The Colebourn Family Archive. (2015). Retrieved from $\mathrm{http} / / /$ therealwinnie.ryerson.ca/collection/scanning.

Remembering the Real Winnie Diaries. (2015). Retrieved from http://therealwinnie.ryerson.ca/collection/.

Remembering the Real Winnie Maps. (2015). Retrieved from https://therealwinnie.ryerson.ca/collection/maps.

Remembering the Real Winnie Photographs. (2015). Retrieved from https://therealwinnie.ryerson.ca/collection/collections/show/3. 